\title{
Hypothermia in Malnourished Jamaican Children
}

Since the description by Trowell and Muwazi (1945) of hypothermia in malnourished children, there have been several publications on this subject from various parts of the African continent (Kahn, 1959; Morley, 1960; Lawless and Lawless, 1963; Brenton, Brown, and Wharton, 1967; Staff, 1968), and it has been stressed that malnourished African children with hypothermia have a poor prognosis. The cause of hypothermia in malnutrition remains in doubt, but Kahn (1959) suggested that it might be due to muscle hypotonia secondary to hypokalaemia, while Lawless and Lawless (1963) proposed that kwashiorkor was a cold injury syndrome.

Protein-calorie malnutrition is prevalent in Jamaica and both nutritional marasmus and kwashiorkor occur. This survey was undertaken for three main reasons: (1) to find the incidence of hypothermia in malnourished Jamaican children (hypothermia is known to be common here, though the climate of the lowland areas is very warm); (2) to see how hypothermia affects the prognosis of these malnourished children; and (3) to find how hypothermia is related to possible causative factors such as hypokalaemia.

\section{Patients and Methods}

Case notes were examined of 137 children who were admitted during 3 years (1965-67) to the Medical

Received 13 December 1971.
Research Council's Tropical Metabolism Research Unit, University of the West Indies, Kingston, Jamaica. The diagnosis of kwashiorkor was made in $37(27 \%)$, of marasmus in 67 (49\%), and of 'marasmic-kwashiorkor' in $33(24 \%)$. All children with kwashiorkor and marasmic-kwashiorkor had oedema. Children in the latter group were also less than $60 \%$ of their expected weight for age (50th centile, Boston Standard). Some details of the patients are given in Table I.

\section{TABLE I}

\section{Clinical Details of 137 Malnourished Children}

\begin{tabular}{l|c}
\hline Total number of children & 137 \\
Male & 94 \\
Female & 43 \\
Mean age (mth) & 10 \\
$\begin{array}{l}\text { Admission weight, \% expected weight } \\
\text { for age }\end{array}$ & $54 \cdot 6$ \\
$\begin{array}{l}\text { Admission weight, \% expected weight } \\
\text { for height }\end{array}$ & $\begin{array}{c}72 \cdot 3) \\
70 \cdot 5 \\
\text { Discharge weight, \% expected weight } \\
\text { for age }\end{array}$ \\
\end{tabular}

The rectal temperatures of all the children were taken 4-hourly, using low-reading clinical thermometers. The lowest temperature recorded during the first week of each child's admission was found from the temperature charts. The arithmetical mean of the 4-hourly temperature readings for the whole week 
was calculated and so was the mean temperature during the week preceding discharge from hospital.

Total body potassium was estimated using a $4 \pi$ whole body liquid scintillation counter (Garrow, 1965) in 80 of the children; serum sodium was estimated in 74 , and serum potassium in 72 using flame photometry.

There were 9 deaths during this 3-year period. Necropsy showed bronchopneumonia in 5, aspiration of stomach contents in 1, and cerebral oedema of unknown cause in 1 . One child had severe gastroenteritis and one died of unknown causes. On admission the children who died were, on average, $53 \%$ of their expected weight for age and $69 \%$ of their expected weight for height (Boston Standards).

In addition, the case notes of 42 out of the 44 children who died in the unit in the period 1960 to 1970 were reviewed. The notes of 2 children could not be traced. During part of this period, temperatures were taken in the axilla. However, low-reading thermometers were used and low temperatures were checked rectally. The mean age of these children was 12 months and they were, on average, $55 \%$ of their expected weight for age at the time of admission. 14 were classified as having kwashiorkor, 12 as having marasmic-kwashiorkor, and 16 as having marasmus.

Necropsies were done on all these children. The main clinical and pathological factors in their deaths were as follows: bronchopneumonia 26 , gastroenteritis 7 , septicaemia 3 , liver failure 3 , measles 1 , purulent pericarditis 1 , cerebral oedema 1 , pulmonary fibrosis 1 , congenital heart disease 1 . There were no abnormal findings apart from severe malnutrition in 6 of the children.

Climate. Jamaica is a tropical island (latitude $18^{\circ} \mathrm{N}$ ) and the lowland areas are hot. Minimum temperatures in February (the coolest month) rarely fall below $15^{\circ} \mathrm{C}$ and are usually in the range of 17 to $18{ }^{\circ} \mathrm{C}$. In summer minimum shade temperatures are around $21^{\circ} \mathrm{C}$ and at maximum reach $34^{\circ} \mathrm{C}$. Relative humidity is generally in the range of 65 to $85 \%$.

The metabolic ward of the unit is a large room containing 14 well-spaced cots. All windows are glazed and can be closed. The ward is not air-conditioned.

\section{Admissions 1965-67.}

\section{Results}

Mean temperatures and incidence of hypothermia. Table II shows the lowest rectal temperatures
TABLE II

Lowest Rectal Temperature During 1st Week of Hospital Treatment (137 Children)

\begin{tabular}{c|c}
\hline Lowest Rectal Temperature & No. of Children \\
\hline$>35.5{ }^{\circ} \mathrm{C}\left(96^{\circ} \mathrm{F}\right)$ & $76(55 \cdot 5 \%)$ \\
$<35.5^{\circ} \mathrm{C}$ & $61(44 \cdot 5 \%)$ \\
$35.4^{\circ} \mathrm{C}\left(95^{\circ} \mathrm{F}\right)$ or less & $27(19 \cdot 7 \%)$ \\
$34.4^{\circ} \mathrm{C}\left(94^{\circ} \mathrm{F}\right)$ or less & $8(5 \cdot 8 \%)$ \\
\hline
\end{tabular}

during the first week of hospital treatment. The lowest rectal temperature recorded was $33.7{ }^{\circ} \mathrm{C}$. The mean rectal temperature of the children after recovery was $36.83{ }^{\circ} \mathrm{C}(\mathrm{SD}=0 \cdot 12)$. This was $0.38{ }^{\circ} \mathrm{C}$ higher than the mean for the group during their first week of hospital treatment $\left(36.45^{\circ} \mathrm{C}\right.$, $\mathrm{SD}=0.23$ ), and $0.52{ }^{\circ} \mathrm{C}$ higher than the mean for the 98 children who were afebrile during their first week $\left(36 \cdot 31{ }^{\circ} \mathrm{C}, \mathrm{SD}=0 \cdot 22\right)$. Both differences were highly significant $(P<0.001)$ when subjected to a ' $t$ ' test applied to paired comparison.

The distribution of the lowest temperature readings among the three clinical varieties of malnutrition was examined. The results are shown in Table III. It can be seen that hypothermia was less often found in kwashiorkor than it was in marasmus and marasmic kwashiorkor, where wasting is more prominent. This difference could be due to the insulating properties of oedema fluid. Some children with kwashiorkor lose oedema rapidly when they are treated. 18 of the 37 children with kwashiorkor in this survey behaved in this way, and 11 of these had neither fever nor gastroenteritis. All these 11 children reached their lowest weight during their second week in hospital. Their mean rectal temperatures in the first and second weeks of hospital treatment were compared, and the results are shown in Table IV. The reduction in mean rectal temperature of $0.24{ }^{\circ} \mathrm{C}\left(0.5{ }^{\circ} \mathrm{F}\right)$ during the second week was found to be significant $(t=3 \cdot 9$, $P<0 \cdot 1$ ) when tested by a ' $t$ ' test applied to paired comparison. In contrast, the 13 afebrile children with kwashiorkor who did not lose oedema rapidly, maintained their rectal temperatures during their

TABLE III

Distribution of Lowest Rectal Temperature Readings During 1st Week of Hospital Treatment in 3 Clinical Varieties of Malnutrition

\begin{tabular}{|c|c|c|c|}
\hline Rectal Temperature & Kwashiorkor (37) & Marasmic-kwashiorkor (33) & Marasmus (67) \\
\hline $\begin{aligned}> & 35 \cdot 5^{\circ} \mathrm{C}\left(96^{\circ} \mathrm{F}\right) \\
< & 35 \cdot 5^{\circ} \mathrm{C} \\
& 35{ }^{\circ} \mathrm{C}\left(95^{\circ} \mathrm{F}\right) \text { or less } \\
& 34 \cdot 4^{\circ} \mathrm{C}\left(94^{\circ} \mathrm{F}\right) \text { or less }\end{aligned}$ & $\begin{array}{l}28(75 \%) \\
8(22 \%) \\
1(3 \%) \\
0\end{array}$ & $\begin{array}{r}3(10 \%) \\
18(54 \%) \\
8(24 \%) \\
4(12 \%)\end{array}$ & $\begin{array}{c}10(15 \%) \\
35(52 \%) \\
18(27 \%) \\
4(6 \%)\end{array}$ \\
\hline
\end{tabular}


second week in hospital. These results are also shown in Table IV.

Seasonal distribution of hypothermia. The seasonal distribution of the cases of severe hypothermia (temperature $35^{\circ} \mathrm{C}$ or less) is shown in Table V. With the exception of January, the distribution was remarkably even throughout the year.

Hypothermia and the degree of malnutrition. Regressions relating rectal temperature to weight and height were calculated for all 137 children. Significant correlations were found and these are shown in Table VI. As might be expected, hypothermia becomes more common with increasing deficit of weight and height.

Hypothermia and electrolyte disturbances. Of the 72 children in whom serum potassium estimations were done on admission, 21 developed severe hypothermia (temperature $35^{\circ} \mathrm{C}$ or less) in the first week. Mean serum potassium level in the hypothermic group was $4.4 \mathrm{mEq} / \mathrm{l} .(\mathrm{SD}=0.80)$, and in the remaining 51 children, it was $4.2 \mathrm{mEq} / 1$. $(\mathrm{SD}=1 \cdot 08)$. These values do not differ significantly. Out of the 80 children who had total body potassium estimations during their first three days in hospital, 10 became severely hypothermic. The mean total body potassium for this group was $37.5 \mathrm{mEq} / \mathrm{kg}(S \mathrm{SD}=6.4)$, while for the remainder (20 children) it was $34.7 \mathrm{mEq} / \mathrm{kg}$ $(\mathrm{SD}=7 \cdot 5)$. Again there was no significant difference between these values. No correlation was found between the mean temperatures in the first week and serum or total body potassium levels.

Since hyponatraemia has been shown to be associated with poor prognosis (Garrow and Pike, 1967), serum sodium values were compared in children who became hypothermic (21) and those who did not (53). The mean for the hypothermic group was $132 \mathrm{mEq} / \mathrm{l}$. (SD $=4 \cdot 5)$, and for the remainder $134 \mathrm{mEq} / \mathrm{l} .(\mathrm{SD}=6 \cdot 0)$. These values do not differ statistically.

Hypothermia and fever. $39(28 \%)$ of the 137 children had a rectal temperature of $37.7^{\circ} \mathrm{C}$ $\left(100^{\circ} \mathrm{F}\right)$ or more at some time during their first week in hospital Of these, 21 also had temperatures below $35.5^{\circ} \mathrm{C}\left(96^{\circ} \mathrm{F}\right)$ in the same period and $8 \mathrm{had}$ readings of $35^{\circ} \mathrm{C}\left(95^{\circ} \mathrm{F}\right)$ or less, showing a remarkable variation in body temperature.

\section{TABLE IV}

Comparison of Mean Rectal Temperature in 1st and 2nd Weeks of Hospital Treatment in Children with Rapid Loss of Oedema and in Those with Slow Loss

\begin{tabular}{|c|c|c|c|c|c|}
\hline & \multirow{2}{*}{$\begin{array}{l}\text { No. } \\
\text { of } \\
\text { Children }\end{array}$} & \multicolumn{2}{|c|}{ Mean Weight (kg) } & \multicolumn{2}{|c|}{ Mean Rectal Temperature $\left({ }^{\circ} \mathrm{C}\right)$} \\
\hline & & 1st Week & 2nd Week & 1st Week & 2nd Week \\
\hline $\begin{array}{l}\text { Rapid loss of oedema } \\
\text { Slow loss of oedema }\end{array}$ & $\begin{array}{l}11 \\
13\end{array}$ & $\begin{array}{c}6.52 \\
(\mathrm{SD}=1.93) \\
6.09 \\
(\mathrm{SD}=2 \cdot 04)\end{array}$ & $\begin{array}{c}5 \cdot 97 \\
(\mathrm{SD}=1 \cdot 70) \\
6 \cdot 12 \\
(\mathrm{SD}=1 \cdot 96)\end{array}$ & $\begin{array}{c}36 \cdot 65 \\
(\mathrm{SD}=1 \cdot 42) \\
36 \cdot 58 \\
(\mathrm{SD}=1 \cdot 38)\end{array}$ & $\begin{array}{c}36 \cdot 41 \\
(\mathrm{SD}=1 \cdot 15) \\
36 \cdot 60 \\
(\mathrm{SD}=1 \cdot 51)\end{array}$ \\
\hline
\end{tabular}

TABLE V

Seasonal Distribution of Severe Hypothermia (Rectal Temperature $<35^{\circ} \mathrm{C}$ ) During 3 Years

\begin{tabular}{c|c|c|c|c|c|c|c|c}
\hline Jan. & Feb. & March & April & May & June & July & Aug. & Sept. \\
\hline 5 & 2 & 2 & 2 & 3 & 2 & 1 & Oct. & Dec. \\
\hline & 2 & 2 & 2 \\
\hline
\end{tabular}

TABLE VI

Relation Between Rectal Temperature and Weight and Height Deficit During 1st Week of Hospital Treatment

Lowest temp. in 1st week $v$ s weight ( $\%$ expected weight for age)

Lowest temp. in 1 st week $v s$ weight (\% expected weight for age)
Lowest temp. in 1 st week $v s$ weight (\% expected weight for height)

Lowest temp. in lst week vs height (\% expected height for age)

Mean temp. in 1 st week $v s$ weight $i \%$ expected weight for age)

Mean temp. in 1 st week $v$ 's weight ( $\%$ expected weight for height)

Mean temp. in 1 st week vs height (\% expected height for age)

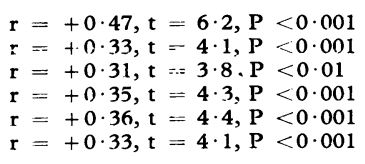


Mortality. 9 of the 137 children died in hospital, a mortality of $6.5 \%$. Of the 61 children who had rectal temperatures of less than $35.5^{\circ} \mathrm{C}$ at some time during the first week, $5(8 \cdot 2 \%)$ died; of these 5,4 had temperature readings of $35^{\circ} \mathrm{C}$ or less in the same period. This represents a death rate of $14.8 \%$ in the group of 27 children with severe hypothermia-more than twice that of the whole group. 3 of the 5 children had pneumonia. The other 2 had no evident infection.

Deaths 1960-70. Since the number of deaths in the 1965-67 survey was small, the study was extended to include 42 children who died in the period 1960-70. The chief causes of death have been summarized above. Thermoregulatory research was not in progress during much of this period, but there was awareness of hypothermia as a complication of severe malnutrition and it is emphasized that temperatures were taken 4-hourly in all children, using low-reading thermometers. Low temperatures were checked rectally during the period in which axillary temperatures were taken as standard (1960-64). For these reasons it is felt that it is valid to compare the incidence of hypothermia in these 42 children with that in the surviving children of the 1965-67 survey. This comparison is shown in Table VII, where it is seen that figures

\section{TABLE VII}

Lowest Rectal Temperatures Recorded Before Death in 42 Children Who Died from Malnutrition, Compared with Those Found in 1st Week of Hospital Treatment in 128 Survivors

\begin{tabular}{l|c|c}
\hline \multirow{2}{*}{ Lowest Rectal Temperature } & No. of Children \\
\cline { 2 - 3 } & Dead & Surviving \\
\hline$>35 \cdot 5{ }^{\circ} \mathrm{C}\left(96^{\circ} \mathrm{F}\right)$ & $30(71 \cdot 4 \%)$ & $68(53 \cdot 1 \%)$ \\
$<35 \cdot 5^{\circ} \mathrm{C}$ & $12(28 \cdot 6 \%)$ & $60(46 \cdot 9 \%)$ \\
$35 \cdot 0^{\circ} \mathrm{C}\left(95^{\circ} \mathrm{F}\right)$ or less & $7(16 \cdot 7 \%)$ & $23(18 \cdot 0 \%)$ \\
$34 \cdot 4^{\circ} \mathrm{C}\left(94{ }^{\circ} \mathrm{F}\right)$ or less & $2(4 \cdot 8 \%)$ & $6(4 \cdot 7 \%)$ \\
& & \\
\hline
\end{tabular}

for temperature readings of $35^{\circ} \mathrm{C}$ and below bear a striking similarity in both groups. Since it has been shown (Table III) that children with kwashiorkor developed hypothermia less often than those with marasmus, it was important to establish that the distribution of marasmus and kwashiorkor was similar between the two groups. Table VIII shows the distribution figures. A $\chi^{2}$ test was made, and showed no statistical difference in the distribution of marasmus, marasmic-kwashiorkor, and kwashiorkor among these groups $\left(\chi^{2}=1 \cdot 45, P>0 \cdot 10\right)$. Of the 12
TABLE VIII

Comparison of Distribution of 3 Clinical Varieties of Malnutrition Among Survivors and Children Who Died

\begin{tabular}{l|c|c}
\hline & Survivors & Dead \\
\hline Kwashiorkor & 35 & 14 \\
Marasmic-kwashiorkor & 32 & 12 \\
Marasmus & 61 & 16 \\
\hline Total & 128 & 42 \\
\hline
\end{tabular}

children who died, 8 who had developed temperatures of $35.5{ }^{\circ} \mathrm{C}$ or less, had severe bronchopneumonia (confirmed at necropsy by gross and histological examination). 2 had liver failure, and 1 died of unknown causes. In the group as a whole, pneumonia was cited as the main cause of death in 25 of the 38 children. Thus the incidence of pulmonary infection was higher in those children who had low temperatures.

\section{Discussion}

Hypothermia is a frequent accompaniment of infantile malnutrition in Jamaica, a factor that has been overlooked in previous descriptions of the symptoms of protein-calorie malnutrition in this country (Garrow, Picou, and Waterlow, 1962; Garrow, 1966; Garrow and Pike, 1967). It is more common in those forms of malnutrition that are characterized by wasting than it is in children with 'classical' kwashiorkor in which weight loss is less marked. This makes it unlikely that the oedema of kwashiorkor is a symptom of cold injury, as suggested by Lawless and Lawless (1963).

With the exception of January, a cool month but not the coolest, the distribution of cases of hypothermia is remarkably even throughout the year, indicating that seasonal variation in ambient temperature is not an important factor in the pathogenesis. Much more important is the degree of weight deficit, as shown by the significant relation between low weight and height and lowered body temperature. This confirms the findings of Brenton et al. (1967), and may reflect a reduced metabolic capacity for heat production in heat-losing environments, as suggested by Kerpel-Fronius, Varga, and Kun (1954). It may also reflect a reduction in thermal insulation, and in this respect the data shown in Table IV are relevant. Rapid loss of oedema in children with kwashiorkor is often an early sign of recovery, and these 11 children should be metabolically more capable of maintaining their body temperatures during their second 
week in hospital than during their first. That they are not implies that the thermal insulation of generalized oedema may be of importance in preventing a fall in body temperature. These findings are at variance with the comments of Jelliffe (1968), who ascribes hypothermia in kwashiorkor to, among other factors, the 'water cooling' effect of generalized oedema.

Hypothermia sometimes occurs during hypoglycaemia (Kerpel-Fronius et al., 1954; Staff, 1968; Wharton, 1970; Brooke, 1972). No hypoglycaemia was recorded in relation to hypothermia in this survey, but this may only mean that hypoglycaemia was not looked for. The association which may occur between these two symptoms supports the theory that hypothermia may be related to deficient energy reserves, and so does the observation that body temperature rises markedly when hypothermic malnourished children are given a high calorie feed (Brooke, 1972). However, there must be other factors involved, since this survey has shown that both hypothermia and fever may occur within a short space of time, long before definite evidence of nutritional improvement has occurred.

The suggestion by Kahn (1959) that hypokalaemia might be the cause of hypothermia in malnourished children was not supported by the findings of this survey. No relation was found between serum or whole body potassium levels and hypothermia or reduced mean body temperature.

The Jamaican experience of hypothermia in malnutrition contrasts with the African. In Jamaican infants rectal temperatures of less than $35.5^{\circ} \mathrm{C}$ $\left(96^{\circ} \mathrm{F}\right)$ are common, occurring in nearly half the admissions, and there is little indication that hypothermia is a sign of poor prognosis. There was an increased mortality in the children who had temperatures of $35^{\circ} \mathrm{C}$ or less in the $1965-67$ series, but the numbers were small and the finding was not confirmed when the records of the 42 dead children were examined. In these children the incidence of hypothermia was similar to the incidence in the survivors of the 1965-67 series, and the only factor to emerge having a possible bearing on prognosis was a higher incidence of pneumonia among the dead children who had been hypothermic. In Africa on the other hand, even mild degrees of hypothermia have a sinister significance and workers in Uganda state that most children die who have temperatures of less than $35.6^{\circ} \mathrm{C}$ (Staff, 1968). Kahn (1959) also commented on the poor prognosis of hypothermic children with kwashiorkor. The reasons for these differences are not clear, but two possible factors are the older age group of the malnourished African children and the higher incidence of kwashiorkor in Africa. Older children less readily become hypothermic than infants, so those who do are likely to be more severely ill. Furthermore, since hypothermia is commoner in marasmic babies than in those with kwashiorkor, the African child with kwashiorkor who develops hypothermia may well be more severely malnourished, and so more likely to die, than his Jamaican counterpart.

Though the outlook for malnourished Jamaican children who develop hypothermia is apparently no worse than for those who do not, it must not be assumed that hypothermia is in itself a benign condition, and its recognition and treatment are of great importance. The harmful effects of hypothermia are well known (Cooper, 1968), and animal studies have shown that death of starved baby pigs can be postponed by raising the ambient temperature (Morrill, 1952). Thus it is recommended that the rectal temperatures of newly admitted malnourished children be taken at no more than 4hour intervals using low-reading thermometers, and that if hypothermia develops it should receive prompt attention. Even in the absence of hypoglycaemia, we have found that a feed invariably increases the body temperature of these hypothermic children and many who have developed hypothermia have been unwilling feeders in the previous 12- to 24-hour period. For this reason as much reliance is placed on frequent feeding, by nasogastric tube if necessary, as it is on physical rewarming, and it is our policy to attempt to establish a high calorie intake as early as possible in the course of the child's admission.

\section{REFERENCES}

Brenton, D. P., Brown, R. E., and Wharton, B. A. (1967). Hypothermia in kwashiorkor. Lancet, 1, 410.

Brooke, O. G. (1972). The influence of malnutrition on the body temperature of children. British Medical fournal, 1, 331.

Cooper, K. E. (1968). Recent Advances in Medicine, 15th ed., p. 345. Ed. by D. N. Baron, N. Compston, and A. M. Dawson. Churchill, London.

Garrow, J. S. (1965). The use and calibration of a small whole body counter for the measurement of total body potassium in malnourished infants. West Indian Medical fournal, 14, 73.

Garrow, J. S. (1966). 'Kwashiorkor' and 'Marasmus' in Jamaican infants. Archivos Latinoamericanos de Nutrición, 16, 145.

Garrow, J. S., Picou, D., and Waterlow, J. C. (1962). The treatment and prognosis of infantile malnutrition in Jamaican children. West Indian Medical fournal, 11, 217.

Garrow, J. S., and Pike, M. C. (1967). The short-term prognosis of severe primary infantile malnutrition. British fournal of Nutrition, 21, 155.

Jelliffe, D. B. (1968). Infant Nutrition in the Subtropics and Tropics (WHO Monograph Series, no. 29), 2nd ed., p. 132. WHO, Geneva.

Kahn, E. (1959). Prognostic criteria of severe protein malnutrition. American fournal of Clinical Nutrition, 7, 161. 
Kerpel-Fronius, E., Varga, F., and Kun, K. (1954). Pathogenese der Dekomposition. II. Die Bedeutung der Anoxie, Hypothermie und Hypoglykaemie im Endzustand der Säuglingsatrophie. Annales Paediatrici, 183, 1.

Lawless, J., and Lawless, M. M. (1963). Kwashiorkor: the result of cold injury in a malnourished child? Lancet, 2, 972.

Morley, D. C. (1960). Cold injury among children severely ill in the tropics. Lancet, 2, 1170.

Morrill, C. C. (1952). Studies on baby pig mortality. X. Influence of environmental temperature on fasting newborn pigs. American Fournal of Veterinary Research, 13, 322.

Staff, T. H. E. (1968). Treatment of severe kwashiorkor and marasmus in hospital. East African Medical fournal, 45, 399.
Trowell, H. C., and Muwazi, E. M. K. (1945). A contribution to the study of malnutrition in Central Africa: a syndrome of ? malignant malnutrition. Transactions of the Royal Society of Tropical Medicine and Hygiene, 39, 229.

Wharton, B. A. (1970). Hypoglycaemia in children with kwashiorkor. Lancet, $1,171$.

Correspondence to Dr. O. G. Brooke, National $\stackrel{\oplus}{\stackrel{D}{\circ}}$ Institute for Medical Research, Division of Human Physiology, Holly Hill, London, N.W.3. 